\begin{tabular}{|l|l|l||}
\hline \multicolumn{2}{|c|}{ PublisherInfo } \\
\hline \hline PublisherName & $:$ & BioMed Central \\
\hline \hline PublisherLocation & $:$ & London \\
\hline \hline PublisherImprintName & $:$ & BioMed Central \\
\hline \hline
\end{tabular}

\title{
Hyperchloraemic acidosis and outcome
}

\begin{tabular}{||l|l|l||}
\hline \multicolumn{2}{|c||}{ ArticleInfo } \\
\hline \hline ArticleID & $:$ & 4318 \\
\hline \hline ArticleDOI & $:$ & $10.1186 /$ ccf-2001-73601 \\
\hline \hline ArticleCitationID & $:$ & 73601 \\
\hline \hline ArticleSequenceNumber & $:$ & 29 \\
\hline \hline ArticleCategory & $:$ & Paper Report \\
\hline \hline ArticleFirstPage & $:$ & 1 \\
\hline \hline ArticleLastPage & $:$ & 4 \\
\hline \hline & & RegistrationDate : 2001-12-5 \\
ArticleHistory & $:$ & Received \\
\hline ArticleCopyright & $:$ & Biomed Central Ltd2001 \\
\hline \hline ArticleGrants & $:$ & \\
\hline \hline ArticleContext & $:$ & 1305455 \\
\hline \hline
\end{tabular}




\section{Keywords}

Abdominal aneurysm repair, hyperchloraemic acidosis, outcome

\section{Context}

Hyperchloraemic acidosis is a consequence of infusions of large quantities of chloride-containing solutions, such as $0.9 \%$ normal saline [NS], although there is no evidence that this influences outcome. This study compared the outcomes of patients undergoing abdominal aortic aneurysm repair who received NS with those given lactated Ringer's (LR) solutions intraoperatively.

\section{Significant findings}

The NS group received statistically more bicarbonate and platelets, and urine output was greater. There were no differences in other outcome variables.

\section{Comments}

This study showed that there were no clinically important outcome differences as a consequence of the fluid therapy that induced a hyperchloraemic metabolic acidosis. However the study was not powered to look at multiple outcome measures and the numbers studied were small. Increased bicarbonate usage is not surprising in the NS group considering the criteria used for bicarbonate administration in this study-a practice that is rarely used in the UK. There is no evidence that acidosis is harmful (therefore buffering is not required) and a recently developed theory argues that acidosis protects against ongoing production of further organic acids (negative feedback loop) and provides a mechanism for cellular metabolic shutdown at times of nutrient shortage such as during ischaemia (see Hood et al. Additional information).

It is not possible to draw conclusions about the differences in urine outputs between the groups since the NS group received a greater amount of fluid, and dopamine and mannitol were used intraoperatively. 
Previous work has suggested that blood loss is greater with NS solutions and, although this trend was apparent, the results were not statistically significant. The increased use of platelets presumably reflects the trend towards a greater cell salvage of blood in the NS group.

In summary this study has shown no outcome benefit for avoiding a hyperchloraemic acidosis during the operative period by the use of LR solutions, although this may represent a type II error.

\section{Methods}

In a randomised double blind study, 33 patients received NS and 33 LR. Outcome measures included the amount of bicarbonate infused (given if base excess $<-5$ ), the amount of blood products used, the duration of ventilation, the length of ICU and hospital stay, and the rate of complications.

\section{Additional information}

Hood VL, Tannen RL: Protection of acid-base balance by pH regulation of acid production.

N Engl J Med 1998, 339:819-826.

See also the associated editorial:

O'Connor, Roizen MF: Lactate versus Chloride: Which is better?

Anesth Analg 2001, 93:809-810.

And the related article:

Wilkes NJ, Woolf R, Mutch M, Mallet SV, Peachey T, Stephens R, Mythen MG: The effects of balanced versus saline-based hetastarch and crystalloid solutions on acid-base and electrolyte status and gastric mucosal perfusion in elderly surgical paptients.

Anesth Analg

93:811-816. 


\section{References}

1. Waters J, Gottlieb A, Schoenwald P, Popovich M, Sprung J, Nelson D: Normal saline versus lactated ringer's solution for intraoperative fluid management in patients undergoing abdominal aortic aneurysm repair: An outcome study. Anesth Analg . 2001, 93: 817-822. 